\author{
Murat Bağcl, \\ Perihan Ergin Özcan, \\ Evren Şentürk, \\ Lütfi Telci, \\ Nahit Çakar
}

\section{Kritik Hastalarda Anemi ve Kan Transfüzyonlarının Değerlendirilmesi}

\author{
Evaluation of Anemia and Blood Transfusions in \\ Critically III Patients
}

Gelis Tarihi/Received : 09.04.2014

Kabul Tarihi/Accepted : 22.04.2014

Türk Yoğun Bakım Derneği Dergisi, Galenos Yayınevi tarafından basılmıștır.

Journal of the Turkish Society of Intensive Care, published by Galenos Publishing.

ISSN: 2146-6416

Perihan Ergin Özcan, Evren Şentürk, Lütfi Telci, Nahit Çakar

Istanbul Üniversitesi Istanbul Tıp Fakültesi,

Anesteziyoloji Anabilim Dalı, Istanbul, Türkiye

Murat Bağcı (凶),

Bağcılar Eğitim ve Araştırma Hastanesi, Anestezi ve

Reaminasyon Kliniği, Istanbul, Türkiye

E-posta: drmurat78@yahoo.com

Gsm: +90 5052407602
ÖZET Amaç: Yoğun bakım ünitesindeki (YBÜ) kritik hastaların takibinde aneminin, morbidite ve mortalite üzerine etkileri tartışılmakla birlikte yapılan çalışmalarda transfüzyon eşik değeri sürekli değişiklik göstermektedir. Çalışmamızda kritik hastalarda anemi varlığında yaklaşım ve tranfüzyon pratiğini değerlendirmeyi amaçladık.

Gereç ve Yöntem: Prospektif ve gözlemsel olarak planlanan çalışmamıza, İstanbul Tıp Fakültesi YBÜ'de 15/05/08-15/11/08 tarihleri arasında yatan 167 hasta dahil edilmiştir. Transfüzyonların en büyük nedeni $(\% 62,7)$ düşük hemoglobin ( $\mathrm{Hb}$ ) olarak tespit edilmiş ve \%90'a yakını ilk üç günde yapılmıştır. Ünitemizde günlük tetkik amaçlı alınan kan miktarı, YBÜ günü başına ortalama 19,2 ml olarak bulunmuştur. Çalışmamızda saptadığımız pretransfüzyon $\mathrm{Hb}$ değeri 7,6 olmakla birlikte, 2/3 gibi büyük oranda transfüzyon eylemi, Hb değeri 7-10 arasında iken yapılmıştır. Bulgular: YBÜ'de transfüzyon yapılanların yapılmayanlara göre daha uzun süre kaldıkları, ölüm oranlarının daha yüksek olduğu saptanmıştır. Hastalara transfüze edilen eritrosit süspansiyonu sayısı arttıkça, mortalite oranlarının da arttığı saptanmıştır. Ayrıca bulduğumuz bu düşük flebotomi miktarının bile literatürler ile paralel olarak, anemiye olumsuz katkısı olduğu kanısındayız. Transfüzyon kararlarının çoğunun hekimin hastaya özgü klinik yaklaşımla verdiği kararlarla uygulandığı, eşik Hb değerinin önemsenmediği gözlemlenmiştir.

Sonuç: Hekimler, hastaların bireysel olarak anemiyi kompanse ve tolore etme yeteneğini hesaba katmalı, transfüzyon endikasyonunu belirlemelidir. Transfüzyonun; immunolojik ve inflamatuar sonuçlarıyla birlikte risk ve yararları düşünülerek en uygun nokta belirlenmelidir.

Anahtar Kelimeler: Anemi, kritik hasta, yoğun bakım ünitesi
SUMMARY Objective: In follow up of critically ill patients that are in intensive care unit (ICU), the effects of anemia on morbidity and mortality are controversial and transfusion threshold values vary in studies. In our study, we purposed to assess approach and transfusion practice in anemia existence in critically ill patients.

Material and Method: In our study that was planned prospectively and observationally, 167 patients staying in Istanbul Faculty of Medicine ICU between 15 May 200815 November 2008 were included. Low hemoglobin (62.7\%) was found to be a major reason for transfusions and nearly $90 \%$ of them were made in first three days. In our unit, daily blood amount for analysis purposes was found to be $19.2 \mathrm{ml}$. per ICU. In our study, however pretransfusion $\mathrm{Hb}$ value was found to be 7.6, two third of transfusions was made when $\mathrm{Hb}$ value was between 7-10

Results: In ICU, it was found that the patients underwent transfusion stayed longer than the other patients and their mortality rates were higher. Mortality rates were found to be increased more and more, as erythrocyte suspension transfused to patients increased. Furthermore, we think that even this phlebotomy amount that we found contributes anemia negatively, in parallel with the information in the literature. It was observed that most transfusion decisions were applied with the decisions that physician made with clinic approach special to patient and threshold $\mathrm{Hb}$ value were not cared.

Conclusion: physicians should regard patients' individual compensation and tolerance capacities and determine transfusion indication. The most appropriate point should be determined regarding risks and benefits of transfusion as well as its immunological and inflammatory its results. Key Words: Anemia, critically ill patient, intensive care unit 


\section{Giriş}

Anemi, kritik hastalarda sık karşılaşılan önemli bir sorundur. Bu nedenle yoğun bakım ünitelerinde (YBÜ) transfüzyon sık uygulanmaktadır. Transfüzyonların nedenleri, etkileri ve sonuçları ile ilgili pek çok çalışma yayınlanmıştır (1-3). Yapılan çalışmalarda YBÜ'ye hastanın kabulünden 3 gün sonra hastaların \%95'inde anemi tespit edildiği bildirilmiştir (1,49). Kan transfüzyonu ihtiyacl; yoğun bakımlarda ileri yaştaki hastaların kronik hastalıklarında artış olması, yaşam destek teknolojisinde ilerleme, YBÜ'de tedavi edilen hastaların sayısı ve hastalık şiddetinin artması, cerrahi ve travma hastalarının yoğun bakım koşullarında daha ileri düzeyde tedavi edilebilmelerine bağlı olarak artmaktadır $(4,5,9)$.

Kritik hastalardaki anemi nedenlerini değiştiren pek çok faktör mevcuttur. Bu faktörlerin anemiye katkısı ve tedavide kullanılan yaklaşımlar çeşitli çalışmalar ile değerlendirilmiştir. Tanı amacıyla kritik hastalardan kan alınması göz ardı edilen ancak aneminin en önemli nedenlerinden biridir. Bu miktar çalışmalarda ortalama 40-41 ml/gün olarak bildirilmiş olup, tanı amaçlı flebotomiler ile eritrosit transfüzyon miktarı arasında pozitif bir korelasyon olduğu da gösterilmiştir (4,5,10-17). Kritik hastalardaki aneminin bir çok nedene bağlı olması nedeniyle hastaların \%29'unda klinisyenlerce endikasyon belirlenemeden transfüzyon yapıldığı, çok fazla transfüzyon yapılan yoğun bakım hastalarında mortalitenin de yüksek olduğu çalışmalarda bildirilmiştir (12-14). Yine aynı çalışmalarda transfüzyon yapılan eritrosit süspansiyonu (ES) ünite sayıs ve YBÜ'de kalış süresi ile ortalama SOFA (Sequential Organ Failure Assessment) skoru arasında anlamlı bir ilişki olduğu bildirilmiş, hastaların APACHE II (Acute Physiology and Chronic Health Evaluation) skorlarının yüksek olduğu ve yatış sürelerinin uzun olduğu vurgulanmıştır $(7,10,18)$.

Günlük olarak bakıldığında dahili $Y B$ hastalarının \%16'sına, cerrahi YB hastalarının \%27'sine kan transfüzyonu yapılmaktadır (19). Kan ürünlerinin transfüzyonu, endikasyon dahilinde kullanıldıklarında hayat kurtarıcı olabilmektedir. Ancak, immunomodülasyon etkisi ile ortaya çıkabilecek otoimmün hastalık ihtimali, kanser nüksü ve nozokomiyal enfeksiyon riskinde artış ihtimali, kan transfüzyonunun güvenilirliğini etkilemiştir.

Yoğun bakım ünitelerinde transfüzyon tedavisi, potansiyel komplikasyonların anlaşılması ve transfüzyon ihtiyacını azaltan ilaçların üretilmesiyle, gelişmekte olan bir alandır.Tüm dünyada transfüzyon ile ilgili çalışmalara bakıldığında yoğun bakımdaki uygulamalar açısından ortak bir görüş benimsenemediği görülmektedir (5). Bu konuyla ilgili ülkemiz şartlarında ortak bir görüş birliği oluşturulması amacıyla yeni çalışmalara ihtiyaç vardır.

Çalışmamızda, hastanemiz YBÜ'de takip edilen hastalarda anemi ve transfüzyon insidansının tanımlanması, transfüzyon için kullanılan eşik Hb değerinin saptanması, transfüzyonun potansiyel yararlarının, transfüzyonla ilişkili risklerin ve transfüzyonun klinik etkilerinin ortaya konulması hedeflenmiştir. Ayrıca tanı amacıyla, kritik hastalardan alınan kan miktarının anemiye olan katkısı araştırılmıştır.

\section{Gereç ve Yöntem}

Çalışmamız prospektif ve gözlemsel bir çalışmadır. Istanbul Tıp Fakültesi Etik Kurul onayı alınarak 15/05/08-15/11/08 tarihleri arasında YBÜ'ye yatan 524 hasta içerisinden çalışmaya dahil olma kriterlerine uyan toplam 167 hasta çalışmaya dahil edilmiştir. Çalışma dışı bırakılma kriterleri; 24 saatten az yatış süresi, 18 yaş altı hastalar ve bazı özel tanılar (yanık, diyaliz uygulanan renal yetersizlikli hastalar) olarak belirlendi.

Çalışma başlangıcında tüm hastaların; alındıkları servis, giriş tanıları, ek hastalıkları, cerrahi operasyon varlığı, mekanik ventilasyon durumu, giriş $\mathrm{Hb}$ değeri ve yatışlarındaki fiziki durumlarının değerlendirmesi için APACHE II ve SOFA skorları kullanıldı. Hastaların takibinde 28 gün boyunca günlük olarak SOFA, mekanik ventilasyon durumu, günlük $\mathrm{Hb}$ değeri (Her sabah 08.00'deki tam kan sayımı sonucu), pretransfüzyon ve posttransfüzyon $\mathrm{Hb}$ değeri, transfüzyon endikasyonu, kullanılan Eritrosit Süspansiyonu (ES) ünite sayısı, komplikasyonlar ve ES dışı yapılan diğer transfüzyonlar kaydedildi. Ayrıca flebotomi miktarları; laboratuvar teknisyenleri tarafından, tetkikler için alınan kan miktarının günlük olarak kaydedilmesi ile hesaplandı.

Hastalar giriş Hb değerlerine göre sınıflandırılıp, hastalık şiddetini gösteren skorlar (APACHE II, SOFA) ile olan ilişkisi incelendi, transfüzyon yapılan ve yapılmayan hastaların giriş $\mathrm{Hb}$ değerlerine göre dağılımı ve mortalite oranları hesaplandı.

Transfüzyon yapılan hastalarda; giriş $\mathrm{Hb}$ değeri ile transfüzyon öncesi en düşük $\mathrm{Hb}$ değeri, transfüzyon yapılmayanlarda ise giriş $\mathrm{Hb}$ değeri ile en düşük $\mathrm{Hb}$ değeri arasındaki fark 'Hb değişim' olarak tanımlandı. Hb değişim kavramı ile flebotomi, transfüzyon ve aneminin şiddeti arasındaki ilişki araştırıldı.

Çalışmada tüm istatistiksel analiz için SPSS for Windows 15.0 versiyonu (SPSS Inc, Chicago, Illinois, USA) kullanıldı. Istatistiksel analizlerde tanımlayıcı istatistikler ve gruplanmış verilerde Ki-Kare testi, normal dağılıma uymayan sürekli değişkenlerde non parametrik testlerden ikili gruplarda MannWhitney U önemlilik testi kullanıldı. Tek değişkenli korelasyon analizi değerlendirilmesinde parametrik değişkenler için Pearson's korelasyon analizi ile değerlendirilirken; nonparametrik değişkenler için Spearman's korelasyon analizi kullanıldı. Parametrelerin birbiri ile çok değişkenli korelasyon analizi değerlendirilmesinde lineer regresyon analizi kullanıldı. Bütün analizlerde $p$ değerinin < 0,05 olması istatistiksel olarak anlamlı kabul edildi. 


\section{Bulgular}

\section{Çalışma grubunun temel özellikleri;}

Çalışma sürecinde YBÜ'ye toplam 524 hasta kabul edildi. Bu hastalar içerisinden çalışmaya dahil edilme kriterlere uygun olan 167 hasta çalışmaya dahil edilmiştir (Şekil 1). Hastaların toplam YBÜ gün sayısı 1459 gün olup, YBÜ'de kalma süreleri

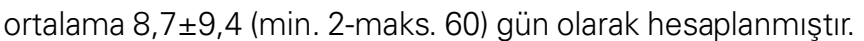

Hastaların YBÜ'ye kabul tanılarına baktığımızda büyük bir kısmı postoperatif dönemde $(\% 34,1)$ ve solunum yetersizliği $(\% 33,5)$ sebebiyle yoğun bakıma yatırımıştır (Tablo 1).

Araştırmaya katılanların yaklaşık yarısının giriş hemoglobin değeri 7-10 gr/dl arasındadır. Hastaların \%61,7'sine ( $n=103$ ) ES transfüzyonu yapılmıştır. Çalışma süresince hastalara toplam 468 ünite ES verilmiştir. Hastalar giriş Hb değerlerine göre sınıflandırılıp, hastalık şiddetini gösteren skorlar (APACHE II, SOFA) ile ilişkisine bakıldığında; girişteki Hb değeri $7 \mathrm{gr} / \mathrm{dl}$ ve altında olanların giriş APACHE II skoru ve giriş SOFA değeri diğerlerinden anlamlı derecede daha yüksektir (Tablo 2).

Yoğun bakında yapılan transfüzyon endikasyonlarına baktığımızda \%63 oranı ile ilk sırayı 'düşük hemoglobin değeri' almaktadır (Tablo 3).

\begin{tabular}{ll}
\hline $\begin{array}{l}\text { Tablo 1. Araştırmaya katılan hastaların giriş nedenlerine göre } \\
\text { dağılımları }\end{array}$ \\
\hline Yoğun Bakım Ünitesine giriş nedenleri & $\mathbf{n}$ \\
\hline Postoperatif takip & $57(\% 34,1)$ \\
Solunum yetersizliği & $56(\% 33,5)$ \\
Nörolojik sorunlar & $11(\% 6,6)$ \\
Sepsis / SIRS & $9(\% 5,4)$ \\
Kardiyovasküler sorunlar & $9(\% 5,4)$ \\
Pnömoni & $6(\% 3,6)$ \\
Travma & $3(\% 1,8)$ \\
ARDS & $2(\% 1,2)$ \\
Primer hematolojik hastalık & $2(\% 1,2)$ \\
Diğer & $12(\% 7,2)$ \\
Toplam & $167(\% 100)$ \\
\hline
\end{tabular}

Veriler hasta sayısı ve yüzdesi olarak belirtilmiştir.

Tablo 2. Hastaların yoğun bakım giriş hemoglobin değerlerine, APACHE II ve SOFA skorlarına göre dağılımları

\begin{tabular}{lll}
\hline $\begin{array}{l}\text { Giriş hemoglobin } \\
\text { değeri }(\mathbf{g r} / \mathbf{d l}) \mathbf{( n )}\end{array}$ & $\begin{array}{l}\text { Giriş APACHE II } \\
\text { skoru }\end{array}$ & $\begin{array}{l}\text { ilk 24 saat içindeki } \\
\text { SOFA değeri }\end{array}$ \\
\hline 7 ve altı (10) & $16,5(15,7-25)^{\star}$ & $9(6-9,2)$ \\
$7-10$ arası (83) & $15(11-19)$ & $5(3-8)$ \\
10 ve üzeri (74) & $13(10-16,2)$ & $4(1-6)$ \\
\hline
\end{tabular}

Veriler ortanca ve 1.-3. çeyreklik olarak verilmiştir. Mann Whitney $U$ testi, ${ }^{*}: p=0,01,9$ : $p<0,001$, APACHE II: Acute Physiologic and Chronic Health Evaluation Score II, SOFA: Sequential Organ Failure Assesment
Çalışmamızda saptadığımız pretransfüzyon Hb değeri 7,6 gr/dl olmakla birlikte, endikasyon verilen 295 transfüzyon olayının dağııımları incelendiğinde; $2 / 3$ gibi büyük oranda transfüzyon eylemi, pretransfüzyon $\mathrm{Hb}$ değeri 7-10 arasında iken yapılmış olup bunlarında \%61,5'i düşük $\mathrm{Hb}$ endikasyonuyla yapılmıştır. Diğer büyük kısmı oluşturan 89 transfüzyon eylemi ise pretransfüzyon $\mathrm{Hb}$ değeri 7 ve altında iken uygulanmış, bunların \%66,3'ü yine düşük $\mathrm{Hb}, \% 31,5^{\prime}$ i hemoraji endikasyonuyla yapılmıştır. Bu durumda, birçok hekimce transfüzyon eşiği olarak teorikte kabul edilen 7 ve altında, yalnızca 89 transfüzyon eylemi uygulanmış olup, 206 transfüzyon eylemi ise hekimin hastaya özgü klinik yaklaşımla verdiği kararla uygulanmıştır (Tablo 4). Hastaların \%90'a

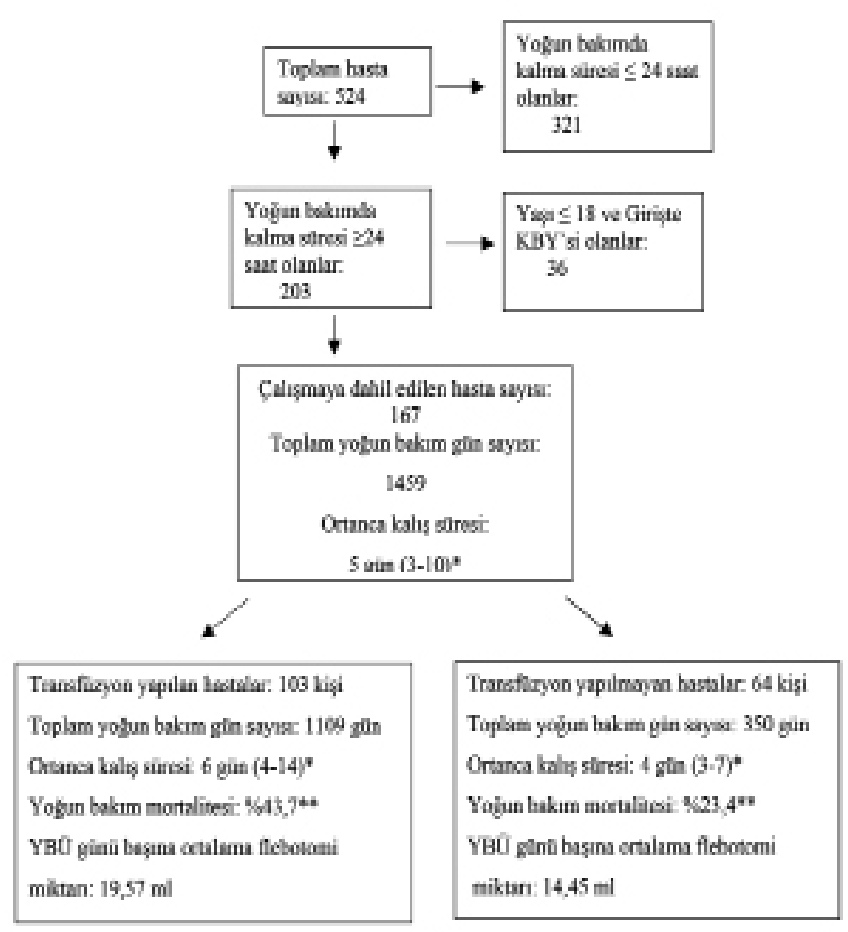

Şekil 1. Çalışma popülasyonunun tanımlanması

\begin{tabular}{ll}
\hline $\begin{array}{l}\text { Tablo 3. Yoğun bakımda yapılan Eritrosit süspansiyonu } \\
\text { transfüzyon olaylarının endikasyonlarına göre dağılımları }\end{array}$ \\
\hline Endikasyon & $\mathbf{n}$ \\
\hline Düşük hemoglobin değeri & $185(\% 62,7)$ \\
Aktif kanama & $49(\% 16,6)$ \\
İskemi & $27(\% 9,2)$ \\
Hemodinamik instabilite & $26(\% 8,8)$ \\
Cerrahi girişim & $7(\% 2,4)$ \\
Kardiyak debiyi arttırmak & $1(\% 0,3)$ \\
Toplam & $295(\% 100)$ \\
\hline
\end{tabular}

Veriler hasta sayısı ve yüzdesi olarak belirtilmiştir. 
yakınına ilk üç gün içinde transfüzyon yapılmıştır. Hastaların yarıya yakınına ise $(\% 47,6)$ yoğun bakımda kaldıkları ilk gün transfüzyon yapılmıştır.

Yoğun bakımdaki hastalardan toplam 26026,5 ml kan alınmıştır. Her bir hastadan alınan kan miktarı ortanca 87,0 (min. 17-maks. 718) ml'dir. YBÜ günü başına hastalardan ortalama 19,2 ml tetkik amaçlı kan alınmıştır. Transfüzyon alan hastaların YB günü başına ortalama flebotomi miktarı $19,57 \mathrm{ml}$ iken, transfüzyon almayanlarda ise $14,45 \mathrm{ml}$ olarak bulunmuştur.

Hastalara verilen ES ünite sayısının gruplar arasındaki mortaliteye etkisi incelendiğinde; transfüze edilen ES sayısı arttıkça mortalite oranlarının da arttığı saptanmıştır (Tablo 5).

\section{Tartışma}

Hastanemiz YBÜ'de takip edilen 167 hasta üzerinde yapılan çalışmamızda; transfüzyonların çok büyük bir kısmının ilk 3 günde gerçekleştiği, ES transfüzyon eşiğinin $7,6 \pm 1,2$ gr olduğu, transfüzyon yapılan hastaların mortalite oranlarının daha yüksek olduğu ve YBÜ'de tetkik için alınan kan miktarının da anemi ile ilişkili olduğu bulunmuştur. Transfüzyon kararlarının çoğunun hekimin hastaya özgü klinik yaklaşımla verdiği kararlarla uygulandığı, eşik Hb değerinin önemsenmediği gözlemlenmiştir.

Anemi, kritik hastalarda sık karşılaşılan önemli bir sorundur ve büyük bir kısmında yoğun bakım ünitesine kabul sırasında anemi mevcuttur. Bizim çalışmamızda da transfüzyonların \%90'a yakınının ilk 3 günde gerçekleşmesi, hastaların YBÜ'ye zaten anemi sınırında gelmiş olabileceklerini ve YB öncesi dönemle ilgili etkenleri düşündürmektedir. Bu hastaların yoğun bakım izlemleri sürecinde bir çok faktöre bağlı olarak anemi insidansı artmakta veya var olan anemi derinleşmektedir (1,4-9). Çalışmamızda, transfüzyonların en büyük nedeni $(\% 62,7)$ düşük Hb değeri olarak tespit edilmiştir. Transfüzyon yapılanların yapılmayanlara göre yoğun bakımda anlamlı derecede daha uzun süre kaldıkları, ölüm oranlarının anlamlı derecede daha yüksek olduğu saptanmıştır.

Kritik hastalardaki anemi nedenleri multifaktöriyeldir. Bu faktörlerden biri olarak tanı amacıyla kritik hastalardan kan alınması, göz ardı edilen ancak aneminin en önemli nedenlerinden biridir. Bu miktar, çalışmalarda ortalama 40-41 ml/gün olarak bildirilmiştir (4). Yapılan çalışmalar tanı amaçlı flebotomiler ile eritrosit transfüzyonu miktarı arasında pozitif bir korelasyon olduğunu göstermiştir (5). Çalışmamızda anemi ciddiyetindeki artışın, flebotomiyle zayıf biçimde korelasyon göstermesine rağmen çok değişkenli regresyon analizi ile flebotominin bağımsız bir etken olduğu saptandı. Çalışmamızda günlük tetkik amaçlı alınan kan miktarı, litaretürdeki ortalamanın altında olup, YBÜ günü başına ortalama 19,2 ml'dir. Bunun sebebi olarak hekimlerin mali disiplin uygulamaları, gereksiz tetkik istekleri açısından uyarılması ve konuyla ilgili literatürlerin hekimlerce dikkate alınması olarak düşünülebilir.

Kritik hastalarda anemiye tolerans; hastanın klinik durumu, eşlik eden komorbiditeler ve dolaşan volüme bağlı olarak değişmektedir. Dolayısıyla hastaların transfüzyon

Tablo 4. Transfüzyondan önceki hemoglobin değerlerinin transfüzyon endikasyonlarına göre dağılımları

\begin{tabular}{|c|c|c|c|c|c|c|c|}
\hline \multirow[b]{2}{*}{$\begin{array}{l}\text { Transfüzyon öncesi } \\
\text { Hb değeri (gr/dl) }\end{array}$} & \multicolumn{7}{|c|}{ Transfüzyon endikasyonu } \\
\hline & $\begin{array}{l}\text { Düşük Hb } \\
\text { değeri }\end{array}$ & Hemoraji & İskemi & $\begin{array}{l}\text { Cerrahi } \\
\text { prosedür }\end{array}$ & $\begin{array}{l}\text { Kardiyak output } \\
\text { arttırmak }\end{array}$ & $\begin{array}{l}\text { Hemodinamik } \\
\text { insitabilite }\end{array}$ & Toplam \\
\hline 7 ve altı & $59(\% 66,3)$ & $28(\% 31,5)$ & - & - & - & $2(\% 2,2)$ & $89(\% 100)$ \\
\hline 7-10 arası & $126(\% 62,4)$ & $21(\% 10,4)$ & $26(\% 12,9)$ & $5(\% 2,5)$ & $1(\% 0,4)$ & $23(\% 11,4)$ & $202(\% 100)$ \\
\hline 10 ve üstü & - & - & $1(\% 25)$ & $2(\% 50)$ & - & $1(\% 25)$ & $4(\% 100)$ \\
\hline
\end{tabular}

Veriler hasta sayısı ve yüzdesi olarak belirtilmiştir. $\mathrm{Hb}$ : hemoglobin

Tablo 5. Yaşayan ve ölen hastaların toplam Eritrosit süspansiyonu miktarı açısından karşılaştırılması

\begin{tabular}{llll}
\hline \multirow{2}{*}{ Toplam ES miktarı } & \multicolumn{3}{c}{ Klinik sonuç } \\
\cline { 2 - 4 } & Servise taburcu & Exitus & Toplam \\
\hline 0 & $49(\% 76,5)$ & $15(\% 23,5)$ & $64(\% 100)$ \\
1 & $17(\% 70,8)$ & $7(\% 29,2)$ & $24(\% 100)$ \\
2 & $11(\% 61,1)$ & $7(\% 38,9)$ & $18(\% 100)$ \\
3 & $7(\% 46,6)$ & $8(\% 53,4)$ & $15(\% 100)$ \\
4 ve $\uparrow$ & $23(\% 50)$ & $23(\% 50)$ & $46(\% 100)$ \\
Toplam & $107(\% 64,1)$ & $60(\% 35,9)$ & $167(\% 100)$ \\
\hline
\end{tabular}

Veriler hasta sayısı ve yüzdesi olarak belirtilmiştir. ES: Eritrosit süspansiyonu 
gereksinimleri ve hangi düzeyde transfüzyon yapılması gerektiği hastanın kliniği ile birlikte değerlendirilmelidir. Bu konuyla ilgili pek çok çalışma bildirilmiştir $(4,6,20-24)$. Chohan ve ark.'nın yaptığı çalışmada ES transfüzyon eşiği 7,8 olarak bildirilirken, Corwin ve ark.'nın yaptığı çalışmada 8,6, Vincent ve ark.'nın yaptığı çalışmada 8,4, Rao MP ve ark.'nın yaptığı çalışmada ise 8,5 olarak belirtilmiştir (25-27). Çalışmamızda literatürlerle uyumlu biçimde ES transfüzyon eşiği olarak $7,6 \pm 1,2 \mathrm{gr}$ bulunmuştur. Ortalama posttransfüzyon $\mathrm{Hb}$ değeri ise 9,3 $\pm 1,2 \mathrm{gr} / \mathrm{dl}$ 'dir. Yapılan toplam 295 transfüzyon kararını incelediğimizde, birçok hekimce transfüzyon eşik değeri olarak teorikte kabul edilen 7 ve altında, yalnızca 89 transfüzyon eylemi uygulanmış olup, 206 transfüzyon eylemi ise hekimin hastaya özgü klinik yaklaşımla verdiği kararla uygulanmıştır. Ancak 7 ve üzerinde yapılan transfüzyonların $\% 61,5$ 'inde transfüzyon endikasyonunun 'düşük $\mathrm{Hb}$ ' olarak tanımlandığı görülüp, bu durumun hekimin endikasyon tanımına yeterli önemi vermemesinden kaynaklandığını düşündürmektedir.

Konuyla ilgili yapılan, transfüzyon tıbbında ilk büyük randomize çalışma, Hebert ve ark.'nın yaptığı “TRICC çalışmasıdır" (23). Sekiz yüz otuz sekiz hastalık bu çalışmada transfüzyon stratejisi ile mortalite ve morbidite arasında güçlü bir ilişki ortaya konmuştur (22). Serbest transfüzyon stratejisi (Hb 10-12 gr/dl arasında tutulduğu ve Hb'nin <10 $\mathrm{gr} / \mathrm{dl}$ olduğunda transfüzyonun yapıldığı grup) ile kısıtlanmış transfüzyon stratejisini ( $\mathrm{Hb}$ 7-9 gr/dl arasında tutulduğu ve $\mathrm{Hb}<7 \mathrm{gr} / \mathrm{dl}$ olduğunda transfüzyon yapıldığı grup) karşılaştırılmıştır. Bu çalışmada transfüzyon sınır endikasyonu $\mathrm{Hb}$ değeri 7-9 gr/dl önerilmiş ve Hb düzeyinin 7 oluncaya kadar transfüzyon yapılmamasının mortaliteyi artırmadığı gösterilmiştir. Kısıtlanmış transfüzyon rejimi ile özellikle 55 yaşından küçük hastalarda daha düşük mortalite oranları (\%6'ya karşlık \%13) elde edilmiştir.

Bizim çalışmamız sürecinde ise yoğun bakımda takip edilen hastaların \%35,9'u kaybedilmiştir. Hastaların yoğun bakıma girişte ek hastalıklarının bulunması ile mortaliteleri arasında anlamlı bir ilişki bulunmadı ancak giriş APACHE II ve SOFA skoru yüksek olan yani kliniği daha kötü olan hastaların daha fazla transfüzyon intiyacı olmuştur. Hastalara verilen ES sayısı artııkça mortalite oranlarının da artıı̆ı saptanmıştır.

Yoğun Bakımda "Anemi ve Kan Transfüzyonu grubunun" ileriye dönük olarak yaptıkları bir başka çalışmada 3534 hasta ele alınmıştır. Transfüzyon uygulananlarda mortalite oranı belirgin daha yüksek (\%29'a karşılık \%14,9, p<0,001) bulunmuştur. Transfüze edilen ünite sayısı arttıkça, mortalite riski de artmaktadır. Ek olarak bu çalışma kan transfüzyonu, organ fonksiyon bozukluğu ve artmış mortalite arasında bir ilişki olduğuna dair kanıtlar sunmaktadır (4).

Amerika Birleşik Devletleri'nde "CRIT çalışması" olarak adlandırılan çalışmada, takibe alınan 4892 hastada (ortalama yaş: 60 yıl) klinik sağ kalım ile anemi ve kan transfüzyonlarının ilişkisi incelenmiştir. Klinik sağ kalım ile transfüze edilen kan miktarının birbirinden bağımsız faktörler olduğu açıklanmıştır (28). APACHE II ve SOFA ile hastalık şiddeti belirlenen hastaların hastalığın ciddiyeti ile transfüzyon ünite sayısı arasında korelasyon bulunmuştur. Ayrıca multivaryant analizlerde transfüzyon yapılan eritrosit süspansiyonu miktarı yoğun bakımda veya hastanede kalış süresinde artma yönünde bir ilişki saptanmıştır.

Yakın zamandaki "SOAP çalışmasında" 3147 kayıtlı hastadan \%33'ü transfüzyon almıştır. Transfüzyon alan ve almayan benzer hastaların mortalite oranları karşılaştııılığında, transfüzyon almayan hastalarda mortalitenin daha yüksek olduğu saptanmıştır. Bu durumda SOAP çalışması; CRIT ve $A B C$ çalışmalarına göre tersini söylemektedir. Çalışmada bu durumun Avrupadaki lökositten arındırma uygulamasından kaynaklanabileceği bildirilmiştir (29).

Bütün bu çalışmalar değerlendirildiğinde anemi tedavisinde asıl amacımı ne olmalı? Sadece düşük $\mathrm{Hb}$ için transfüzyon gerçekleştirirsek, elbette $\mathrm{Hb}$ düzeyini yükseltmeyi başarırız. (Her 1 Ü ES için $1 \mathrm{~g} / \mathrm{dl}$ ) Fakat birçok klinisyen; oksijen sunumunu ve kullanımını arttırmayı ana hedef olarak görmektedir. Kuşkusuz oksijen sunumu anemide azalır (30). Ancak, gerekli O2 sunumunu arttırma girişimlerine rağmen, doku oksijenasyonu veya $\mathrm{O} 2$ kullanımını arttıran sonuçlara ulaşılamamıştır (31).

Prospektif randomize kontrollü çalışmalar ve metaanalizlerde, oksijen kullanımı ve oksijen sunumunun normal üstü değerlerinin temin edilmesinin faydalarının doğrulanması sağlanamamıştır. Ayrıca bu stratejinin belki de kötü klinik sonuçlar ve artan mortaliteyle sonuçlanabileceğini bildirmişlerdir. Bu tartışmalara rağmen çoğunlukla klinik amaç, kritik hastaların tedavisinde oksijen sunumunu düzeltmektir (31).

Henüz kritik hastalarda Hb 5 ile $7 \mathrm{~g} / \mathrm{dl}$ arasında transfüzyonun fayda ve zararlarını araştıran çalışma bulunmamaktadır. Bir çok merkezli çalışmada transfüzyonu reddeden hastalarda postoperatif çıkıslarında, $\mathrm{Hb}<5,1$ $\mathrm{g} / \mathrm{dl}$ olduğunda net olarak artan mortalite ve morbidite gösterilmiştir (32).

Anemi değerlendirmesi; $\mathrm{Hb}$ ve Hct ölçümleri ile yapılır. Dolaşımdaki eritrosit kitlesi ile plazma arasındaki ilişkide düşünülmelidir. Kritik hastalarda; her ikisini birden ciddi biçimde değiştiren bir çok faktör vardır. Anemi varlığında, tedavi ve patofizyoloji aynı anda değerlendirilmelidir. Bu ayrıntı büyük çalışmalarda sıkça belirsizdir çünkü ölçümü zor, pahalı, istatistiksel analizi sağlayacak sınıflandırma zordur (8).

Yoğun bakım ünitelerinde kan transfüzyonu sıklıkla uygulanmakta, transfüzyon sınırları konusunda belirlenmiş protokoller bulunmamaktadır. Transfüzyon uygulamalarında ciddi değişkenlik görülmekte, aneminin etkin tedavisi ve klinik 
sağkalım üzerine etkisi tam olarak tanımlanamamaktadır. YBÜ'deki değişik tipteki hasta popülasyonuna standart bir transfüzyon protokolü uygulanamaz. Ayrıca hastaların bireysel olarak anemiye toleransı transfüzyon konusunda karar verirken en önemli faktördür. Her bir hastanın akut $\mathrm{Hb}$ düşüşüne karşı kompansasyonunu incelemek gerekir. Bugün transfüzyon pratiğindeki en büyük sorun; bireysel olarak anemiye tolerans ve adaptasyonun tespit edilmesindeki zorluktur.

\section{Sonuç}

Hekimler, hastaların bireysel olarak anemiyi kompanse ve tolore etme yeteneğini hesaba katmalı, transfüzyon endikasyonunu belirlemeli ve sadece $\mathrm{Hb}$ değerini temel alarak transfüzyon kararı vermemelidir. Transfüzyonun; immunolojik ve inflamatuar sonuçlarıyla birlikte risk ve yararları da düşünülerek ideal nokta belirlenmelidir.

\section{Çıkar Çatıșması}

Yazarlar herhangi bir çıkar çatışması bildirmemişlerdir.

\section{Kaynaklar}

1. Nguyen BV, Bota DP, Melot C, Vincent JL. Time course of hemoglobin concentrations in nonbleeding intensive care unit patients. Crit care Med 2003;31:406-10.

2. DeBellis RJ. Anemia in critical care patients: incidence, etiology, impact, management, and use of treatment guidelines and protocols. Am J Health Syst Pharm 2007;64:14-21.

3. Hebert PC, Tinmouth A, Corwin $\mathrm{H}$. Anemia and red cell transfusion in critically ill patients. Crit Care Med 2003;31:672-7.

4. Vincent JL, Baron JF, Reinhart K, Gattinoni L, Thijs L, Webb A, et al. Anemia and blood transfusion in critically ill patients. JAMA 2002;288:1499-507.

5. Corwin HL, Parsonnet KC, Gettinger A $\mathrm{RBC}$ transfusion in the ICU. Is there a reason? Chest 1995;108:767-71.

6. Chohan SS, McArdle F, McClelland DB, Mackenzie SJ, Walsh TS. Red cell transfusion practice following the transfusion requrements in critical care (TRICC) study: prospective observational cohort study in a large UK intensive care unit. Vox Sang 2003;84:211-8.

7. Corwin $\mathrm{HL}$, Gettinger $A$, Pearl RG, Fink MP, Levy MM, Abraham E, et al. The CRIT Study: Anemia and blood transfusion in the critically ill-Current clinical practice in the United States. Crit Care Med 2004;32:39-52.

8. Walsh TS, Saleh EE. Anaemia during critical illness. Br J Aneesth 2006;97:278-91.

9. Corwin $\mathrm{HL}$, Gettinger $A$, Rodriguez RM, Pearl RG, Gubler KD, Enny C, et al. Efficacy of recombinant human erythropoietin in the critically ill patient: a randomized, double-blind, placebo-controlled trial. Crit Care Med 1999;27:2346-50.

10. Vincent JL, Baron JF, Reinhart K, Gattinoni L, Thijs L, Webb A, et al. Anemia and Blood Transfusion in Critically ill Patients. JAMA 2002;288:1499-507.
11. Low LL, Harrington GR, Stolzfus DP. The effect of arterial lines on blood-drawing practices and costs in intensive care units. Chest 1995;108:216-9.

12. Napolitano LM. Scope of the problem: epidemology of anemia and use of blood transfusions in critical care. Critical Care 2004:8:1-8.

13. Timouth AT, Mclntyre LA, Fovler RA. Blood conservation strategies to reduce the need for red blood cell transfusion in critically ill patients. CMAJ 2008;178:49-57.

14. Corwin HL, Surgenor SD, Gettinger A. Transfusion practice in the critically ill. Crit Care Med 2003;31:668-71.

15. Vincent JL, Sakr Y, Creteur J. Anemia in the intensive care unit. Can J Anesth 2003;50:53-9.

16. Scharte M, Fink MP. Red blood cell physiology in critical illness. Crit Care Med 2003;31:651-7

17. Rogers JT. Ferritin translation of IL-1 and IL-6: the role of sequences up stream of the start codons of the heavy and light subunit genes. Blood 1996;87:2525-37.

18. Rao MP, Boralessa $H$, Morgan C, Soni N, Goldhill DR, Brett SJ, et al. Blood component use in critically ill patients. Anaesthesia 2002;57:530-4.

19. Corwin $\mathrm{HL}$, Abraham $\mathrm{E}$, et al. Anemia and blood transfusion in the critically ill: Current clinical practice in the US. Crit Care Med; 2001;29(Suppl):A3.

20. Hébert PC, Wells G, Martin C, Tweeddale M, Marshall J, Blajchman M, et al. Variation in red cell transfusion practice in the intensive care unit: a multicentre cohort study. Crit Care 1999;3:57-63.

21. Carson JL, Hill S, Carless P, Hebert P, Henry D. Transfusion triggers: a systematic review of the literature. Transfus Med Rev 2002;16:187-99.

22. Hébert PC, Wells G, Blajchman MA, Marshall J, Martin C, Pagliarello G, et al. A multicenter, randomized, controlled clinical trial of transfusion requirements in critical care. Transfusion Requirements in Critical Care Trials Group. N Engl J Med 1999;340:409-17.
23. Hébert PC1, Wells G, Martin C, Tweeddale M, Marshall J, Blajchman M, et al. A Canadian survey of transfusion practices in critically ill patients. Crit Care Med 1998;26:482-7.

24. Marshall JC. Transfusion trigger: when to transfuse? Crit Care 2004;8:31-3.

25. The Association of Anaesthetists of Great Britain and Ireland: Blood Transfusion and the Anaesthetists.' [http://www.aagbi.org/ guidlines.html] (Accessed 29th December 2002).

26. Scottish Intercollegiate Guidelines Network: Perioperative Blood Transfusion For Elective Surgery: A National Clinical Guideline. www document.[http://www. sign.acuk] (Accessed 29 th December 2002).

27. McClelland DBL(ed): Handbook of Transfusion Medicine. www document. [http://www.transfusionguidelines.org.uk] (Accessed 29th December 2002).

28. Corwin $\mathrm{HL}$, Gettinger A, Pearl RG, Fink MP, Levy MM, Abraham E, et al. The CRIT Study: Anemia and blood transfusion in the critically ill-current clinical practice in the United States. Crit Care Med 2004;32:39-52

29. Vincent JL, Sakr Y, Sprung CL, Ranieri VM, Reinhart K, Gerlach H, et al. Sepsis in European intensive care units: results of the SOAP study. Crit Care Med 2006;34:344-53.

30. Cavill I. Eritropoiesis and iron. Best Pract Res Clin Haematol 2002;15:399-409.

31. Hebert PC, Van der Linden P, Biro G, Hu LQ. Physiologic aspects of anemia. Crit Care Clin 2004;20:187-212.

32. Carson JL, Noveck H, Berlin JA, Gould SA. Mortality and morbidity in patients with very low postoperative $\mathrm{Hb}$ levels who decline blood transfusion. Transfusion 2002;42:812-8. 